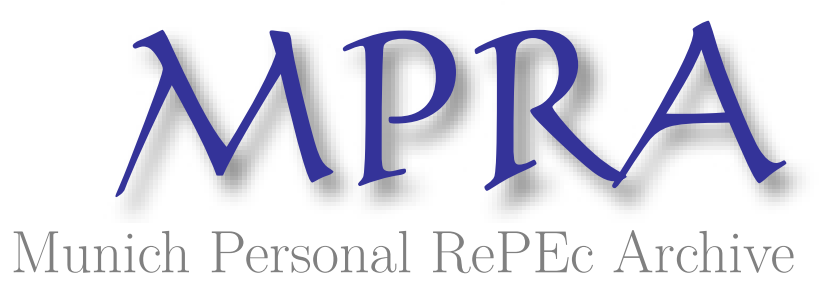

\title{
Institutional interactions and economic growth: The joint effects of property rights, veto players and democratic capital
}

Justesen, Mogens K. and Kurrild-Klitgaard, Peter

November 2013

Online at https://mpra.ub.uni-muenchen.de/51773/

MPRA Paper No. 51773, posted 02 Dec 2013 06:12 UTC 


\title{
Institutional interactions and economic growth: The joint effects of property rights, veto players and democratic capital
}

MOGENS K. JUSTESEN

Dept. of Business and Politics, Copenhagen Business School

PETER KURRILD-KLITGAARD

Dept. of Political Science, University of Copenhagen

\begin{abstract}
We investigate the possible interaction effects that the extent of property rights protection and separation of powers in a political system have on economic growth. Using analysis of panel data from more than countries over the period 19702010 we find that the growth effects of property rights increase when political power is divided among more veto players. When distinguishing between institutional veto players (political institutions) and partisan veto players (fractionalization among political parties), we further find that the growth effects of property rights are driven mainly by checks on the chief executive (in bicameral systems) and primarily found in countries with large stocks of democratic capital.
\end{abstract}

Keywords: Economic growth; institutions; property rights; veto players; democracy. JEL-codes: D72; E02; O17; O43; P14; P16; P48.

"Where an excess of power prevails, property of no sort is duly respected. No man is safe in his opinions, his person, his faculties, or his possessions. [...] Government is instituted to protect property of every sort; as well that which lies in the various rights of individuals, as that which the term particularly expresses. This being the end of government, that alone is a just government, which impartially secures to every man, whatever is his own. [...] That is not a just government, nor is property secure under it, where the property which a man has in his personal safety and personal liberty, is violated by arbitrary seizures of one class of citizens for the service of the rest." 


\section{Introduction}

Recent decades have witnessed an explosion in the interest in the factors potentially determining economic growth (cf. Barro 1997; Barro and Sala-i-Martin 2004). This is not least the case for studies of the potential growth-inducing effects of political institutions. ${ }^{1}$

However, while the protection of property rights often is found to be important for economic growth, many other results from the empirical research on the institutional determinants of economic growth seem either ambivalent or contradictory. Most notably, researchers have so far failed to reach anything remotely resembling consensus on the effects of democracy on economic growth, with studies finding both positive and negative relationships, non-linear relationships and no effects at all, or, for that matter, that causality goes in the opposite direction. ${ }^{2}$ Something similar may be said about the potential growth effects of the extent of the dispersion of political power among political actors, where the possible effects are tested against both theories and the empirical results show both positive and negative consequences.

However, very few studies have considered the possible combined economic growth effects of (a) the extent of property rights protection and (b) the extent to which political power is shared among "veto players", i.e., political actors who may be able to block changes to the status quo. The purpose of the present study is to consider the possible interaction effects of the two: Are any effects (positive or negative) of one or the other in reality less important in themselves than how they may condition each other?

We consider this question by, first, presenting the standard arguments for why property rights are important for economic growth, and the divergent views on the effects separation of powers

\footnotetext{
1 See, e.g., North and Thomas (1973); Weaver and Rockman (1993b); Kasper and Streit (1998); Borner and Paldam (1998); Scully (2001); Acemoglu, Johnson and Robinson (2001); Rodrik, Subramanian and Trebbi (2004); and Haan (2007).

2 Compare, e.g., Helliwell (1994); Barro (1996, 1997); Doucouliagos and Ulubasoglu (2008); and Gundlach and Paldam (2009).
} 
(section 2). But, what is more important, we suggest-in line with the arguments of Melton (2013) and Justesen (2014) - that property rights matter for economic growth mainly in institutional contexts wherein political power is divided among a number of political actors. Such arrangements work as formal mechanisms that affect the ability of governments to change existing property rights at some point in the future and, while a system of checks-and-balances need not directly affect the "strength" or "quality" of property rights, it does affect their credibility. For this reason, we expect that strong property rights in isolation are insufficient to generate economic growth. Rather the growth effects of property rights tend to become stronger as their credibility increases, i.e., when political power is divided among several political actors.

We then outline the empirical strategy to be followed and identify the relevant data (section 3.1). The statistical analyses with regard to institutional interactions (section 3.2) and democratic capital (section 3.3) are presented next. Relative to prior work (Justesen 2014; cf. Justesen and Kurrild-Klitgaard 2007), this paper makes the following contributions to the literature. First, we examine the interactions of property rights and veto players for a large number of countries over a longer time horizon (40 years). Second, rather than relying only on broad indices of power sharing, we decompose the veto player index developed by Witold Henisz in order to separate measures of purely institutional veto players from partisan veto players, generated by the outcomes of elections (Henisz 2000, 2002, cf. Henisz [2002] 2010). Third, we compare the interaction effect for countries that have experienced political regime changes in their recent history versus countries with stable political regimes. The final section summarizes and concludes (section 4).

\section{Property rights, veto players and economic growth}

Institutional economists and public choice theorists have in recent decades drawn attention not only to the fact that economic systems across the modern world are embedded in political systems, but also 
to how the economic behavior of market actors may be influenced by the nature of the political institutions governing them (North 1990: 48; Weingast 1995).

Property rights are the rights of individuals to undertake actions with regard to their own persons, including labor supply, and the disposition of the goods and services they possess (North 1990: 33). Property rights are influenced by political institutions to the extent that the latter affect 1 ) the set of permissible actions and strategies, both political and private, and 2) the relative prices of choosing one action (political or economic) rather than another (Brennan and Hamlin 1995: 288). Political institutions thus create a structure of incentives that will influence the economic behavior of individuals as well as their political choices. When institutions impose costs and benefits on actions these will tend to reduce some types of behavior and encourage other types relatively more so; both will affect the coordination of economic actions and determine the extent of institutional limits on the powers of political decision-makers, i.e., the costs of making political decisions and what the content of them must or cannot be (Buchanan 2000). The existence of private property rights and efficient enforcement both of those rights and of contracts will contribute to defining such an incentive structure, and any set of institutional arrangements will tend to affect the relative costs or benefits of different types of behavior (cf. Buchanan 2000).

\subsection{Protection of property rights}

The theoretical arguments for the economic importance of private property rights are well-established and straightforward: Effective protection of private property rights enables economic actors to plan ahead and gives them sufficient incentives to invest in capital (Smith [1776] 1981; Mises [1949] 1966; Hayek 1960; Friedman 1962; Kasper and Streit 1998; Pipes 1999). It also reduces transaction costs (Coase 1960; North 1992), both in economic transactions and in political decision-making (Buchanan and Tullock [1962] 2004; Bernholz 
2012). Economic actors will enter only into those exchanges that they expect to be mutually beneficial, and if property rights are well protected and markets are free of interference, significant room for reaping gains from exchange exists, and the long-term consequence contributes to society's welfare. Fundamentally, economic growth presupposes that the actions and interactions of individuals are productive, and a regime of well-defined property rights encourages them to engage in productive behavior and trade rather than in destructive, exploitative and purely redistributive behavior (Mises [1927] 2005; Rothbard 1956; Olson 2000). In this manner, a system in which property rights are protected tends to align individual's interests with society's interests so as to enhance cooperation and foster economic growth.

In contrast, without any protection of property rights, actors are likely to find themselves in a Prisoners' Dilemma-like setting resembling a Hobbesian state-of-nature, where everyone will have an incentive to shift their behavior from productive to predatory (Tullock 1974; Buchanan [1975] 1999). In Hobbes's famous words:

In such condition there is no place for industry, because the fruit thereof is uncertain: and consequently no culture of the earth; no navigation, nor use of the commodities that may be imported by sea; no commodious building; no instruments of moving and removing such things as require much force; no knowledge of the face of the earth; no account of time; no arts; no letters; no society; and which is worst of all, continual fear, and danger of violent death; and the life of man, solitary, poor, nasty, brutish, and short. (Hobbes [1651] 1991, §62: 88-89)

Property rights may be said to be secure when individuals are entitled to use and transfer what they own free of aggression by others (including the government itself), and insecure when rights are unclear, unprotected or both. Protection of property rights may come in a number of different forms and may include a cluster of institutions, including efficient enforcement against public and private predation, e.g., constitutional restrictions on expropriation ("takings"), parliamentary procedures and limitations regarding 
taxation and, more generally and indirectly, an independent judiciary that constrain the exercise of executive authority, i.e., the police powers of the state (Acemoglu, Johnson and Robinson 2005). In general, it will also presuppose, inter alia, effective enforcement of contracts and a system of tort and criminal law.

All in all, economic reasoning suggests that secure property rights are a necessary precondition for economic growth to occur (Leblang 1996; Asoni 2008). So far, the results of empirical research largely have confirmed these expectations: Most studies find a strong, positive correlation between secure private property and economic growth. ${ }^{3}$ However, studies also exist suggesting, e.g., that those correlations are weak or non-existent (Barro and Sala-i-Martin 2004; Glaeser et al. 2004), that improvements in property rights rankings are not correlated with economic growth, or that the results depend crucially on the samples of countries studied (Martínez and King 2010; Fails and Krieckhaus 2010).

\subsection{Separation of powers}

\subsubsection{THE CREDIBILITY OF PROPERTY RIGHTS PROTECTION}

A fundamental political dilemma for any political-economic system lies in the fact that a government must be strong enough to enforce property rights in general for social and economic interactions to be productive, but that the government's strength simultaneously may pose a potential threat against the very rights it was supposed to protect (Weingast 1995: 1). Cf. Madison's famous reasoning in Federalist No. 51 in defense of separation of powers:

3 See, e.g., Torstensson (1994); Goldsmith (1995); Knack and Keefer (1995); Clague et al. (1996); Leblang (1996); Keefer and Knack (1997); Carlsson and Lundström (2002); O'Driscoll and Hoskins (2003); Claessens and Laeven (2003); Acemoglu and Johnson (2005); Berggren and Jordahl (2005); and Berggren, Bergh and Bjørnskov (2012); cf. Asoni (2008). 
If men were angels, no government would be necessary. If angels were to govern men, neither external nor internal controls on government would be necessary. In framing a government which is to be administered by men over men, the great difficulty lies in this: you must first enable the government to control the governed; and in the next place oblige it to control itself. A dependence on the people is, no doubt, the primary control on the government; but experience has taught mankind the necessity of auxiliary precautions. (Hamilton, Jay and Madison [1787] 2001: 269).

This is feature-that political decisions often are reversible and that a majority may undo what another has done-creates an asymmetry, a "time inconsistency problem": The government may at one point promise not to do something at a future time, but then later have an incentive not to honor this promise (cf. Blanchard and Fischer 1989: 592). If an investor fears that a government has an incentive to expropriate property or suddenly and arbitrarily to increase the tax rate on profits ex post, this will create an incentive for postponing the investment, changing it or abstaining altogether from engaging in it. The decisions of economic actors with regard to investment, production, trade, and so on, accordingly depend not only on previous or contemporary policies and institutions but also, and not least, on their expectations regarding the policies and institutions that will regulate their decisions at some later time (Kydland and Prescott 1977: 474). This is, in essence, a question of credible commitment: The government's ability to bind itself to a set of institutions and policies that will protect private property and generally be conducive to economic growth will be crucial when it comes to stimulating (or impairing) productive behavior (North and Weingast 1989; Weymouth 2011; Melton 2013).

\subsubsection{VETO PLAYERS AND THE STATUS QUO}

It is with respect to expectations that a separation of political powers and the existence of veto powers potentially become important. A veto player may in this context be defined as a political actor whose 
consent (or at least nil obstat) is necessary in order for a change to take place in the political status quo, i.e., in order to change a set of existing policies (Tsebelis 2002: 19; cf. Tsebelis 1995). If there is more than one veto player, all must agree before a change in the status quo is possible. The number and configuration of veto players in a political system accordingly defines the extent of separation of powers within the system: The more actors or institutions whose agreement is necessary to effect change in the political status quo, the more veto players there may be said to be.

The important effects of a strong (rather than weak) separation of powers is that by adding to the number of veto players institutionalizes a requirement of unanimity among the relevant actors, and this (a) forces the consideration of a larger set of policy preferences and (b) thereby increases the transaction costs of collective decision-making relative to situations where fewer or only one political actor has the discretionary power to make the ultimate decision. ${ }^{4}$ It therefore becomes harder to impose external costs on minorities and, everything else being equal, limits decisions to those that represent Pareto improvements-but, of course, with more than one possible consequence

On the other hand, it has long been argued in constitutional thought that widespread separation of powers in general will lead to policies that are growth promoting, if nothing else because they will prevent bad policies from being implemented (Buchanan and Tullock [1962] 2004). To wit, in a system with only one political actor (say, an absolutist king or a de facto unconstrained parliament) it takes the decision of only one player to ram through policies with potentially very detrimental growth effects (e.g., large-scale nationalizations or confiscatory taxes). In contrast, in a political system such as that of the United States, policies will need to pass with majorities in both the House of Representatives and the Senate (and with sufficiently broad support in the latter to override any

\footnotetext{
4 On the nature of political transaction costs, see, e.g., Buchanan and Tullock ([1962] 2004) and Berggren and Karlson (2003).
} 
"filibuster" attempts), not be met with a presidential veto and not be struck down by the Supreme Court, should the legislation elicit a lawsuit (cf. Madison [1792] 1906: 101-03; Federalist No. 10, 47 \& 51, in Hamilton, Jay and Madison [1787] 2001; Grofman and Wittman 1989). In total, such a large number of veto players and hurdles correspond to requiring a quite high qualified political majority (Miller and Hammond 1989). By giving various interests in society the ability to block decisions-Madisonian reasoning arguespolicies may become more stable and government more trustworthy, thus providing indirect support for a growth-friendly environment (Weingast 1993, 1995; cf. North and Weingast 1989).

However, the other side of the coin is that many veto players may make it harder to implement policies that may be widely beneficial, but are unpopular with small minorities that may be able to block them. It can similarly be argued that the separation of powers between multiple veto players cannot be expected to lead to a particularly growth-promoting set of policies, because the situation simply creates a "lock in" of existing policies at a status quo leveland the status quo might not itself be hospitable to economic growth (Tsebelis 2002: 204).

That side of the issue has been argued all the way from the Thomas Hobbes's defense of "Leviathan" to various modern day, almost neo-Hobbesian political scientists who have emphasized the positive effects of political decision-makers unilaterally being able to make decisions and implement them as costless as possible (cf., e.g., Weaver and Rockman 1993a) and, in contrast, pointed towards the negative consequences of blocking minorities. The latter institutionalizes a "conservative" bias that hampers political flexibility and perhaps leads to a suboptimal supply of public goods (Cox and McCubbins 2001). In this view, the consequence of multiple veto players may be institutional "grid-lock" caused by conflicts between two or more veto players (e.g., a parliament and a president), in extreme cases making it impossible to take necessary political decisions in response to, for example, changes in macroeconomic conditions related to negative, exogenous chocks to 
the economy (Cox and McCubbins 2001: 29-30; Linz 1994: 8-10). An illustrative example may be the US experience since the 1970s, where divergent interests in Senate, House of Representatives and White House have made agreement on how to balance the budget impossible and, hence, lead to dramatic deficits and the accumulation of a $\$ 17$ trillion public debt.

The potential economic benefits of a political system with multiple veto players (greater credibility and stability) accordingly must be balanced against the potential costs in the form of an inability to make the proper decisions when they are needed. If such arguments are correct, then we should not expect the existence of multiple veto players to have a particularly positive effect on economic growth.

The divergent theoretical expectations have been matched by the results of empirical research into the field of veto player effects on economic growth, which so far have been less than unequivocal in their conclusions. Several studies have found at least some empirical indications that the number of veto players in a political system may be associated with positive economic growth (Henisz 2000, 2002; Keefer and Knack 1997), not least when one of the veto players is an independent judiciary (Feld and Voigt 2003). However, other studies have found no or even negative correlations between the number of veto players and economic growth (e.g., Kurrild-Klitgaard 2003).

\subsection{The joint importance of property rights and veto players}

Very few studies have attempted to look simultaneously at the possible economic growth effects of the two institutional factors studied herein-the extent of property rights protections and the number of veto players in the political system-and even fewer at 
the possible combined effects of the two. ${ }^{5}$ However, it makes sense to argue that simple promises of property rights' protection or an extensive separation of powers in themselves may not be enough to create the institutional framework necessary for economic growth (Wagner 1993; Kurrild-Klitgaard and Berggren 2004). For a market economy genuinely to operate at its fullest, limits on predation (public and private) and a dispersion of political power both are needed (Friedman 1962: 2f). Furthermore, it is plausible that the effect of interactions between degrees of political power separation (as measured by the number of veto players) and strengths of property rights protections will differ across countries having divergent political experiences.

\subsubsection{INTERACTION EFFECTS}

To illustrate this, let us take the most optimistic scenario: It makes sense to suggest that if private property rights are strongly protected, and if the constitutional arrangements are such that (owing to to separation of powers) it will be difficult to take such protection away, a climate will exist wherein plans for the future can be made confidently and, hence, economic growth is fostered In this sense, the combination of strong property rights and political powers divided among veto players works as "assurance" for investors, increasing their certainty that investments will not be subject to arbitrary property rights violations or various forms of unanticipated "hard" or "soft" expropriation now or in the foreseeable future (Marshall and Stone 2012). Examples include the nineteenth and twentieth century United States, contemporary Switzerland and many other western societies.

On the other hand, the most pessimistic scenario must be seen as being one where only poor or non-existent protections of private property are in place, and where political power is highly

\footnotetext{
${ }^{5}$ Exceptions are Melton (2013) and Justesen (2014). See also Kurrild-Klitgaard (2003); Justesen and Kurrild-Klitgaard (2007).
} 
concentrated, e.g., in the hands of a de facto dictator. Under such a scenario economic actors will be at the whim of the decision-makers: They may have possessions, but these can easily be taken away. Illustrative examples are often found in weakly institutionalized and economically less developed countries and might include, e.g., Tsarist Russia, Sub-Saharan Africa, the American colonies in the 17th and $18^{\text {th }}$ centuries and much of the Middle East since the end of the First World War.

In between these extremes are two other scenarios. In the one, property rights are given legal protection but with weak separation of powers and the former accordingly may be changed quite easily. In the other, political power is widely and effectively dispersed but property rights not well protected: In this case the insecure property rights are, so to speak, "locked in", because predatory veto players will be able to block changes that would have made property rights more secure. It seems plausible to suggest that these latter environments will be less conducive to economic growth than the first mentioned scenario, but at least marginally more so than the second scenario (Justesen 2014). In other words, we get a relation that looks as follows with respect to whether property rights are secure or insecure and the separation of powers strong or weak:

Strong \& secure > (strong \& insecure; weak \& secure) $>$ weak \& insecure.

That is, we would expect economic growth to be more rapid when a nation's politico-economic environment is characterized by both secure property and institutionalized power sharing, and lowest when neither of the two is present. Viewed in this way, political institutions with veto players may therefore work as a conditioning variable that will moderate the links between property rights and economic growth. In reality then, it is the interaction between veto players and property rights that matters for economic growth, rather than either one in isolation (Justesen 2014). 


\subsubsection{INSTITUTIONAL VETO PLAYERS VERSUS PARTISAN VETO}

\section{PLAYERS}

We have written above of veto players in the abstract, but in practice they may come in different forms (Tsebelis 1995). Two types of veto players can be identified: institutional veto players, explicitly defined by a formal constitutional arrangement, e.g., a president and one or more legislative chambers whose assent is necessary for laws to be enacted and signed into law, courts with the power of judicial review, binding referendums and so on, all comprising a formal system of checks and balances. Alternatively, they may be partisan veto players, i.e., political actors elected to a parliament under the banners of majority and minority political parties or grouped together in coalitions in a multiparty government. In either case, one party or party coalition may be able to block action by the other. An example is the Conservative-Liberal Democrat coalition in United Kingdom formed in 2010.

There are good reasons to believe that the empirical effects of one type of veto player may be quite different from the other, depending on the context, e.g., government stability (Tsebelis 1995, 2002) or fiscal policy stance (Dahl 2014). It is plausible that the extent to which veto players are either institutional or partisan also may influence their effect on property rights protection, and there are at least two reasons for this.

First of all, institutional veto players (e.g., in the form of a bicameral legislature) are in a sense more central to collective decision-making than partisan veto players. In the former case, agreement between the veto players is necessary to effect a change; in the latter, agreement between them is, strictly speaking, neither necessary nor sufficient (Tsebelis 1995: 302f). Second, one may expect that veto players who are institutional in nature are more "credible" than partisan veto players, because their configurations are relatively harder to change deliberately and more unlikely to change rapidly and repeatedly. Parties' strengths go up and down from election to election and may occasionally be crucially dependent on solitary individuals; fundamental political institutions 
(typically set out in a constitution) change more slowly and disappear only rarely. ${ }^{6}$ Together these considerations suggest that an increase in the number of institutional veto players is more likely to have effects similar to those usually associated with a separation of powers than is an increase in the number of partisan veto players.

\subsection{The importance of "democratic capital"}

While the previous points suggest that the economic effects of property rights vary according to the political power-sharing arrangements in place, but these effects in and of themselves may materialize only under certain conditions. Recent contributions to the literature on democracy and economic growth have particularly highlighted systematic performance differences between countries with low and high stocks of "democratic capital", i.e., historical experiences with democracy.7 Specifically, countries with low stocks of democratic capital (often young democracies) tend to perform worse on a range of economic, institutional, and political indicators than countries with larger stocks of democratic capital (often older, more consolidated democracies). ${ }^{8}$

In this perspective, differences between countries' stocks of democratic capital may also affect the way property rights and power sharing institutions operate, and the extent to which investors and voters are confident that these institutions are durable. Kapstein and Converse (2008: 32-33) argue that young democracies differ from older democracies in two key respects. First, transitions into democracy are likely to be followed by periods of uncertainty,

\footnotetext{
${ }^{6}$ See also Krehbiel (1996), who demonstrates that there are reasons to believe that the mere presence of institutional veto players, irrespective of their partisan leanings, will be able to provide "gridlock".

7 See Gerring et al. (2005); Gerring, Thacker and Alfaro (2012); Keefer (2007); Kapstein and Converse (2008); and Persson and Tabellini (2009).

${ }^{8}$ See Keefer (2007); Gerring et al. (2005); Gerring, Thacker and Alfaro (2012); and Persson and Tabellini (2009).
} 
where powerful actors may renege on their prior commitments to support the institutions of democracy, and where the new rules of the game are weakly institutionalized (Gerring et al. 2005: 332-333). As emphasized by Gerring et al. (2012: 3), this means that, "in a new democracy there is little assurance that the democratic framework will hold". That conjecture is supported by empirical evidence suggesting that the likelihood of democratic reversals declines with rising stocks of democratic capital (Kapstein and Converse 2008: 4041; Persson and Tabellini 2009), implying that the democratic regime within which investors and businesses operate becomes more stable. In comparison, the uncertainty created by the potential for regime reversals in young democracies may adversely affect investors' confidence in economic institutions, such as property rights that protect their investments and division of political powers that "lock in" property rights over time. By implication, the joint growth effect of property rights and veto players may be offset in young democracies precisely because of the risk of regime reversals.

Secondly, as Keefer (2007) argues, politicians in young democracies are often unable to make credible commitments to deliver broad-based policies, and voters therefore generally do not trust the election promises of politicians. As a result, politicians often switch to electoral strategies relying on clientelistic networks, which may result in under-provision of public goods and oversupply of private goods, the producers of which have captured rents through the political process (Keefer 2007).

If the under-provision of public goods includes the rule of law and property rights protections, problems of credible commitment in the electoral arena may also weaken investment incentives for economic agents. Moreover, like voters, investors too may have little confidence in the policy promises of politicians in young democracies. This may partly be due to the risk of regime reversals, but it may also be caused by the fact that it takes time for parties and governments to build reputations for, e.g., delivering public goods, maintaining economic institutions, and honoring contracts (cf. Keefer 2007: 806). Economic agents may therefore be reluctant to 
undertake investments and place business activities in young democracies, even if institutions like property rights and political power sharing are established formally. Because of comparatively high risks of regime reversals and the credibility problems facing governments in young democracies, we expect that institutions-in our case the interaction of property rights and veto players-will have weaker economic effects in countries with low stocks of democratic capital. But as democracy becomes more consolidated and - at least in expectations - is considered to be "the only game in town" (Linz and Stepan 1996), the uncertainty associated with regime reversals in newly established democracies is reduced. We therefore expect the joint growth effect of property rights and veto players to materialize chiefly in democracies with relatively large stocks of democratic capital.

\section{Statistical analysis}

On the basis of the previous discussion we can now approach the issue of how to translate theory into empirical research. First of all, we would expect political systems with a strong interaction between property rights protection and the number of veto players to be associated with faster economic growth (section 2.3.1). We also expect that the interaction effect will be stronger in political systems characterized by institutional veto players rather than partisan veto players (section 2.3.2). Finally, we expect that the growth effects will be stronger in countries with higher rather than lower stocks of "democratic capital" (section 2.4).

\subsection{Research strategy and data}

To estimate the growth effect of the interaction of property rights and veto players, we run a series of fixed effects regressions, given by (1), for more than 100 developed and developing countries during the period 1970-2010. The panel is organized at five-year 
intervals, where economic growth is measured as the first difference of the natural logarithm of real GDP per capita, using data from the Penn World Table (PWT), version 7.1.

$$
\text { GROWTH }_{i, t}=\beta_{1} P R_{i, t-1}+\beta_{2} V P_{i, t-1}+\beta_{3} P R_{i, t-1} x V P_{i, t-1}+\delta \operatorname{CONTROLS}_{i, t-1}+\alpha_{i}+\lambda_{t}+\mu_{i, t}
$$

As a proxy for property rights (PR), we use the Property Rights \& Legal System component from the Fraser Institute's Economic Freedom index (Gwartney et al. 2011); veto players (VP) are measured using Henisz's index of Political Constraints (POLCONIII, Henisz [2002] 2010); and PRxVP is the multiplicative interaction term. These measures of property rights and veto players are used widely in the literature (Henisz 2000; Li and Resnick 2003; Nyström 2008; Justesen and Kurrild-Klitgaard 2007; Justesen 2008; Melton 2013). All regressions contain country $\left(\alpha_{\mathrm{i}}\right)$ and period $\left(\lambda_{\mathrm{t}}\right)$ fixed effects. The country fixed effects capture the impact of all timeinvariant factors, such as geography and colonial history, while the period fixed effects account for global events that are common to all countries.

To guard against spurious correlation, we also include a set of lagged time-varying control variables that may affect both economic growth and selection into particular institutional regimes. The control variables are fairly standard in the growth literature and include the measure of electoral contestation developed by Przeworski et al. (2000) and updated by Cheibub, Gandhi and Vreeland (2010); regime stability from the POLITY IV data; battle deaths from the PRIO/Uppsala conflict data to account for the impact of violent conflict; population growth (PWT 7.1, Heston, Summers and Aten 2011); average years of schooling as a proxy for human capital (Barro and Lee 2010); trade volumes (PWT 7.1); and a measure of oil production from the BP Statistical Review of World Energy (2012) to control for "resource curse" effects (Sachs and Warner 2001; Ross 2012; Paldam 2013). We also include $\ln ($ real GDP per capita) to account for convergence effects (Barro 1996, 2012). 
However, using the (first) lag of GDP per capita as a right-handside variable in growth regressions means that equation (1) corresponds to estimating a dynamic model with a lagged dependent variable (Caselli, Esquivel and Lefort 1996; Barro 2012). In fixed effects regressions, this creates biased estimates because of correlation between the lagged dependent variable and the error term - the so-called "Nickell bias". The size of the bias is inversely related to the time dimension (Nickell 1981; Barro 2012), which is quite small $(\mathrm{T}=8)$ in our panel. In addition to the standard fixed effects regressions, we therefore address the Nickell bias by estimating equation (1) using Arellano-Bond GMM regressions (Arellano and Bond 1991; Caselli, Esquivel and Lefort 1996; Acemoglu et al. 2008). Detailed variable descriptions and summary statistics are available in the appendix.

\subsection{Results}

\subsubsection{INTERACTION EFFECTS OF PROPERTY RIGHTS AND VETO PLAYERS}

Results for the growth regressions including the institutional interaction term are shown in Table 1, both for the full sample of countries (World) and for a subsample of less-developed countries (LDCs). ${ }^{9}$ All models contain a multiplicative interaction term, as well as it constituent terms (Brambor, Clark and Golder 2006: 66-70).

\section{[Table 1 about here]}

The odd-numbered columns in Table 1 show results from fixed effects regressions using OLS estimation, while the even-numbered columns show corresponding results obtained using Arellano-Bond

LDCs are defined as all countries outside West Europe, North America, Australia, New Zealand, and Japan. 
GMM estimation. Models 1 and 2 show results for the full sample of countries and models 3 and 4 replicate these models for the LDC subsample. While the interaction term is positive in all models, the coefficients are larger in LDCs, suggesting that the interaction of property rights and veto players has bigger effects in this group of countries. It is well-know that the interaction effect is not revealed fully by the coefficients of the interaction terms (Brambor, Clark and Golder 2006). Figures $1 \mathrm{a}$ and $1 \mathrm{~b}$ therefore show plots of the marginal effect of property rights at varying values of political constraints, with $90 \%$ confidence intervals given by the dotted lines.

\section{[Figures 1a and $1 \mathrm{~b}$ about here]}

Figures $1 \mathrm{a}$ and $1 \mathrm{~b}$ show how the effect of property rights varies as the values of political constraints change from weak to strong along the horizontal axis. For both plots, it is clear that the interaction effect is positive and becomes significant at relatively modest values of the political constraints variable. Substantially, this means that as governments face more political and institutional constraints, the average growth effect of property rights increases, all else equal. This implies that property rights matter more in political systems that divide power among multiple veto players. In contrast, the economic growth effect of property rights is small and insignificant in political systems where power is concentrated in the hands of only one veto player. These results corroborate the findings of Justesen (2014), who reports similar results albeit only for developing countries and over a shorter time period (1970-2000).

\subsubsection{DIFFERENCES BETWEEN INSTITUTIONAL AND PARTISAN}

\section{VETO PLAYERS}

While Justesen (2014) uses the composite measure of political constraints as a proxy for veto players, models 5-12 expand upon this work by decomposing the POLCON index into two variables that serve as proxies for institutional and partisan veto players, 
respectively. First, we construct a simple measure of the number of legislative chambers $(0,1$, or 2$)$ in the political system, using data from Henisz's political constraints dataset, and use this variable as a proxy for the number of institutional veto players. Second, we use Henisz's index of legislative fractionalization as a proxy for the number of partisan veto players in the lower chamber. In this way, we are able to make a rough distinction between institutional and partisan veto players.

In models 5-8, we interact property rights with the number of legislative chambers, and in models 9-12 we interact property rights with legislative fractionalization. The coefficients of the interaction of property rights and legislative chambers are consistently positive, while the interaction of property rights and legislative fractionalization appears to be weaker and closer to zero.

\section{[Figures $2 a$ and $2 b$ about here]}

Figures $2 \mathrm{a}$ and $2 \mathrm{~b}$ illustrate the interaction effects and their statistical significance. Figure $2 \mathrm{a}$ shows the marginal effect of property rights and how it changes as the number of legislative chambers increases, all else equal. Interestingly, the effect of property rights strengthens as the number of legislative chambers increases, but becomes significant only above values of one (1) on the measure of legislative chambers. That is, property rights start to have positive and significant effects on economic growth when some division of power between the executive and legislative veto players is introduced.

Figure $2 b$ shows that the relationship is somewhat different when it comes to partisan veto players. Firstly, while the marginal effect of property rights increases slightly as legislative fractionalization increases, it is quite weak. Secondly, the growth effect of property rights is just barely significant at medium values of legislative fractionalization, and disappears if we include data for all 
countries. ${ }^{10}$ This might suggest some positive conditioning effects of moderate degrees of power sharing among partisan veto players (Cox and McCubbins 2001). However, since this result is quite weak, we hesitate to conclude that legislative fractionalization has a particularly robust conditioning effect on the relationship between property rights and economic growth. Rather, the results suggest that particularly institutional veto players-measured as legislative "checks" on the executive-increase the growth-promoting effects of property rights, while the conditioning effects of partisan veto players are weaker. To the best of our knowledge, these are new results that have not previously been reported in the literature.

Our interpretation of the differing conditioning effects of institutional and partisan veto players is that institutional veto players are likely to create an environment where status quo property rights are relatively more credible and stable. Institutional veto players are often more durable and subject to change only in the longer run. In contrast, partisan veto players and legislative fractionalization are directly affected by election outcomes, and therefore subject to changes in the shorter term, which may render existing property rights less credible. Institutional veto players may therefore serve as a more enduring credibility mechanism than partisan veto players. Of course, this means that institutional veto players contribute to increasing economic growth only when the property rights that exist in the status quo are strong (Justesen 2014). If status quo property rights are weak, institutional veto players may serve to block institutional reform to a greater extent than partisan veto players, and thereby contribute to weaken economic growth. ${ }^{11}$

\footnotetext{
${ }^{10}$ Additional plots are available upon request.

${ }^{11}$ The coefficients of the constituent terms on the veto players variables in Table 1 show the effect of veto players when the value of the property rights variable is zero (Brambor, Clark and Golder 2006), corresponding to a situation with weak property rights. In such cases, the coefficients indicate that institutional veto players have negative effects on economic growth.
} 
However, when status quo property rights are strong and coupled with political institutions that make them difficult to change, investors receive a credible signal that property rights are both strong now and can be relied upon in the future. This is likely to create strong incentives for economic agent to undertake the investments required for generating economic growth.

\subsubsection{INSTITUTIONAL INTERACTIONS AND DEMOCRATIC CAPITAL}

While the results above suggest that the interaction effect of property rights and veto players is quite strong, this section proceeds by testing the interaction effect in subsamples of countries with low and high stocks of "democratic capital". As outlined in the theory section, we expect the growth effects of institutionsincluding the interaction of property rights and veto players - to be weaker in countries with low levels of democratic capital than in countries with higher levels of democratic capital. In Table 2, we test these conjectures by dividing countries into two groups: One with low stocks of democratic capital, and one with higher stocks of democratic capital. In order to separate small and large stock countries, we use the Przeworski et al. (2000) democracy indicator, updated by Cheibub, Gandhi and Vreeland (2010). Using these data, we calculate the accumulated number of years a given country has been a democracy during the period we examine. In Table 2, countries that have a minimum of one (1) and a maximum of ten (10) years of experience with democracy are coded as having low stocks of democratic capital. This means that we exclude from the analyses countries that have no experience with democracy, i.e., stable non-democracies. ${ }^{12}$ Countries with more than ten (10) years of

\footnotetext{
${ }^{12}$ Note that Przeworski et al. (2000) and Cheibub, Gandhi and Vreeland (2010) both code Botswana as a non-democracy because the same political party has held office since democratic elections were introduced there. This coding is controversial, since Botswana it mostly regarded as long-standing democracy (Robinson and Parsons 2006). However, in our case, dropping it ensures that
} 
democratic experience are coded as having large(r) stocks of democratic capital. ${ }^{13}$ To ensure that the results are not driven by consolidated democracies in the Western world, the sample consists only of less developed countries (LDCs) with at least one year of experience with democracy according to the data of Cheibub, Gandhi and Vreeland (2010).

\section{[Table 2 about here]}

Table 2 shows results from regressions testing the growth effect of the interaction of property rights and veto players in countries with low and high(er) stocks of democratic capital, respectively. Model 1 tests the interaction between property rights and the composite POLCON measure in countries with low stocks of democratic capital. Model 2 replicates this regression in countries with high stocks of democratic capital. Models 3 and 4 reproduce models 1 and 2 using GMM regression. Consistent with our expectationsand the broader views in the literature (Keefer 2007) - the results of models 1-4 show that the coefficient of the interaction term is roughly twice as large in countries with high stocks of democracy compared to low stock democracies.

\section{[Figures $3 a$ and $3 b$ about here]}

To illustrate, Figures $3 \mathrm{a}$ and $3 \mathrm{~b}$ show the marginal effect of property rights at different values of veto players with corresponding $90 \%$ confidence levels, based on models 1 and 2, respectively. Figure $3 a$ clearly shows that although the interaction of property rights and veto players is positive, it clearly is insignificant across all values of veto players. That is, in countries with low stocks of democratic capital-including young democracies-the joint growth effect of

the results are not driven by the presence of Botswana in the group of countries with high stocks of democratic capital.

13 The results are similar if we chose, e.g., 15 or 20 years of democratic experience as the cut-off point. 
property rights and veto players is weak and insignificant. In contrast, Figure $3 \mathrm{~b}$ shows that in countries with high stocks of democratic capital, the interaction of property rights and veto players is positive and becomes more significant as the number of veto players increases. These results clearly suggest that while the growth effect of property rights increases as political power is divided among more veto players, this effect materializes chiefly when countries achieve more extensive experience with democracy and where democracy, by implication, is more institutionalized and less susceptible to reversal.

In models 5-8 we interact property rights with the index of legislative chambers. These results corroborate the finding that the interaction effect is weaker in low-stock democracies and matters mainly in high-stock democracies. Finally, models 9-12 include the interaction of property rights and legislative fractionalization. While the interaction is positive in high stock democracies, the variable's explanatory power is not robust and becomes insignificant across all values of veto players in model 12. (Plots of marginal effects are available upon request.)

These results therefore suggest two patterns in the relationship between property rights, veto players, and economic growth: First, institutional veto players rather than partisan veto players drive the interaction effect. Second, the growth effect of the interaction of property rights and institutional veto players is found mainly in countries with large stocks of democratic capital. Overall, we find that the growth effect of property rights increases when institutional veto players make property rights institutions credible and hard to change, and that this effect applies primarily to political regimes that have relatively extensive experiences with democracy. In countries with low stocks of democratic capital-including young democracies-institutions have a much weaker effect on economic growth. These results are consistent with recent empirical contributions to the literature (Gerring et al. 2005; Gerring, Thacker and Alfaro 2012; Keefer 2007; Kapstein and Converse 2008; Persson and Tabellini 2009) in the sense that the economic effects of 
institutions weaken in countries that are young democracies, have limited experience with democratic forms of government in their recent histories, or both.

\section{Conclusion}

In the present study we have found support for the classic Madisonian view: That a government that is limited in what it (and the citizens) may do with respect to private property rights, reinforced by a separation of political powers, will be one that is hospitable to economic growth and accordingly to long term prosperity.

This view is-as indicated-classic, but the present study adds substantially to the empirical research on the topic. We have added further to the studies suggesting that well-protected property rights are important for economic growth, but also to the more novel insight that property rights protection alone may not be sufficient. As such, the analysis has contributed to the debate over whether constitutions are "guns" (that act with force) or merely "parchment" (that may be ignored) (cf. Wagner 1993; for empirical studies, see, e.g., Vanssay and Spindler 1994). Specifically, we have provided three important insights:

First, that "mere promise" of property rights protection is not enough to generate economic growth but may need to be embedded in a political system with separation of powers in order to be credible. The actors in political systems wherein power rests in the hands of only one "player" may offer promises, but may also change their minds-and for that reason they will tend to grow more slowly. These results are novel relative to prior studies that have not looked at the interaction (Kurrild-Klitgaard 2003; Justesen and Kurrild-Klitgaard 2007), include fewer, less "global" observations (Melton 2013; Justesen 2014) or focus on other dependent variables, such as capital investments or foreign exchange rates (e.g., Weymouth 2011; Marshall and Stone 2012) 
Second, we find that not all veto players are equal: The positive growth effects of property rights given a separation of powers is in reality due to institutional veto players rather than simply more political parties. It is legislative "checks" on the executive that increase the growth effects of property rights, while the conditioning effects of partisan veto players are weaker. This is an altogether novel result.

Third and finally, we find - which is novel but consistent with the literature on young democracies-that the growth effects of institutions weaken in countries with low stocks of "democratic capital", i.e., countries that are young democracies and/or have limited experiences with democratic forms of government in their recent histories. For these countries, the main challenge seems to be to consolidate the nascent regime and "hang on" to democratic institutions, even though the early stages of democracy may produce only weak economic results.

All in all, our results substantiate the claim that constitutions are not simply "parchment" promises but have real effects, including for the living standards of the citizens.

Acknowledgements: The authors wish to thank Bill Shughart, Christian Bjørnskov and the participants in the Paldam Workshop for helpful comments.

\section{References}

Acemoglu, D. \& Johnson, S. (2005). Unbundling institutions. Journal of Political Economy 113(5), 949-995.

Acemoglu, D., Johnson, S., \& Robinson, J. (2001). The colonial origin of comparative development: An empirical investigation. American Economic Review 91(5), 1369-1401.

Acemoglu, D., Johnson, S., \& Robinson, J. (2005). Institutions as the fundamental cause of long-run growth. In P. Aghion \& S. N. Durlauf (Eds.), Handbook of economic growth (pp. 385-464). Amsterdam: North-Holland. 
Acemoglu, D., Johnson, S., Robinson, J. A., \& Yared, P. (2008). Democracy and income. American Economic Review 98(3), 808-842.

Arellano, M. \& Bond, S. (1991). Some tests of specification for panel data: Monte Carlo evidence and an application to employment equations. Review of Economic Studies 58(2), 277-297.

Asoni, A. (2008). Protection of property rights and growth as political equilibria. Journal of Economic Surveys 22(5), 953-987.

Barro, R. J. (1996). Democracy and growth. Journal of Economic Growth 1, 1-27.

Barro, R. J. (1997). Determinants of economic growth: A cross-country empirical study. Cambridge: MIT Press.

Barro, R. J. (2012). Convergence and modernization revisited National Bureau of Economic Research.

Barro, R. J. \& Lee, J.-W. (2010). A new data set of educational attainment in the world, 1950-2010., NBER Working Paper No. 15902, http://www.nber.org/papers/w15902.

Barro, R. J. \& Sala-i-Martin, X. X. (2004). Economic growth (2 ed.). Cambridge: MIT Press.

Beck, T., Clarke, G., Groff, A., Keefer, P., \& Walsh, P. (2001). New tools and new tests in comparative political economy: the Database of Political Institutions. World Bank Economic Review 15, 165-176.

Berggren, N., Bergh, A., \& Bjørnskov, C. (2012). The growth effects of institutional instability. Journal of Institutional Economics 8(2), 187-224.

Berggren, N. \& Jordahl, H. (2005). Does free trade really reduce growth? Further testing using the Economic Freedom Index. Public Choice 122(1-2), 99-114.

Berggren, N. \& Karlson, N. (2003). Constitutionalism, division of power and transaction costs. Public Choice 117(1-2), 99-124.

Bernholz, P. (2012). From The Calculus of Consent to extended logrolling, negative externalities, and the Coase theorem. Public Choice 152(3-4), 265271.

Blanchard, O. J. \& Fischer, S. (1989). Lectures on macroeconomics. Cambridge: MIT Press.

Borner, S. \& Paldam, M. (Eds.) (1998). The political dimensions of economic growth. London: Macmillan.

Brambor, T., Clark, W. R., \& Golder, M. (2006). Understanding interaction models: Improving empirical analyses. Political Analysis 14(1), 63-82.

Brennan, G. \& Hamlin, A. P. (1995). Constitutional political economy: The political philosophy of homo economicus? Journal of Political Philosophy 3(3), 280-303.

Buchanan, J. M. ([1975] 1999). The limits of liberty: Between anarchy and leviathan, The Collected Works of James M. Buchanan, Vol. 7, G. Brennan, H. Kliemt, \& R. D. Tollison (Eds.). Indianapolis: Liberty Fund. 
Buchanan, J. M. (2000). Why constitutions matter. In N. Berggren, N. Karlson, \& J. Nergelius (Eds.), Why constitutions matter (pp. 1-16). Stockholm: City University Press.

Buchanan, J. M. \& Tullock, G. ([1962] 2004). The calculus of consent: Logical foundations of constitutional democracy, The Selected Works of Gordon Tullock, Vol. 2, C. K. Rowley (Ed.). Indianapolis: Liberty Fund.

Carlsson, F. \& Lundström, S. (2002). Economic freedom and growth: Decomposing the effects. Public Choice 112(3-4).

Caselli, F., Esquivel, G., \& Lefort, F. (1996). Reopening the convergence debate: A new look at cross-country growth empirics. Journal of Economic Growth 1(3), 363-389.

Cheibub, J. A., Gandhi, J., \& Vreeland, J. (2010). Democracy and dictatorship revisited. Public Choice 143(1-2), 67-101.

Claessens, S. \& Laeven, L. (2003). Financial development, property rights, and growth. Journal of Finance 58(6), 2401-2436.

Clague, C., Keefer, P., Knack, S., \& Olson, M. (1996). Property and contract rights in autocracies and democracies. Journal of Economic Growth 1(2), 243276.

Coase, R. H. (1960). The problem of social cost. Journal of Law and Economics 3, 144.

Cox, G. W. \& McCubbins, M. D. (2001). The institutional determinants of economic policy outcomes. In S. Haggard \& M. D. McCubbins (Eds.), Presidents, parliaments and policy (pp. 21-63). Cambridge: Cambridge University Press.

Dahl, C. H. (2014). Parties and institutions: Empirical evidence on veto players and the growth of government. Public Choice, forthcoming.

Doucouliagos, H. \& Ulubasoglu, M. A. (2008). Democracy and economic growth: A meta-analysis. American Journal of Political Science 52(1), 61-83.

Fails, M. D. \& Krieckhaus, J. (2010). Colonialism, property rights and the modern world income distribution. British Journal of Political Science 40(3), 487-508.

Feld, L. P. \& Voigt, S. (2003). Economic growth and judicial independence: Cross country evidence using a new set of indicators. European Journal of Political Economy 19(3), 497-527.

Friedman, M. (1962). Capitalism and freedom. Chicago: University of Chicago Press.

Gerring, J., Bond, P., Barndt, W. T., \& Moreno, C. (2005). Democracy and economic growth. World Politics 57, 323-364.

Gerring, J., Thacker, S. C., \& Alfaro, R. (2012). Democracy and human development. Journal of Politics 74(1), 1-17. 
Glaeser, E. L., La Porta, R., Lopez-de-Silanes, F., \& Shleifer, A. (2004). Do institutions cause growth? Journal of Economic Growth 9(3), 271-303.

Goldsmith, A. A. (1995). Democracy, property rights and economic growth. Journal of Development Studies 32(2), 157-174.

Grofman, B. \& Wittman, D. (Eds.) (1989). The Federalist Papers and the new institutionalism. New York: Agathon Press.

Gundlach, E. \& Paldam, M. (2009). A farewell to critical junctures: Sorting out long-run causality of income and democracy. European Journal of Political Economy 25(3), 340-354.

Gwartney, J. D., Lawson, R., Hall, J., Chauffur, J.-P., \& Stroup, M. D. (2011). Economic freedom of the World: 2011 annual report. Vancouver: Fraser Institute.

Haan, J. d. (2007). Political institutions and economic growth reconsidered. Public Choice 131(3-4), 281-292, Presidential address, European Public Choice Society conference, Turku, April 2006.

Hamilton, A., Jay, J., \& Madison, J. ([1787] 2001). The Federalist (Gideon ed.), G. W. Carey \& J. McClellan (Eds.). Indianapolis: Liberty Fund.

Hayek, F. A. v. (1960). The constitution of liberty. London: Routledge \& Kegan Paul.

Helliwell, J. F. (1994). Empirical linkages between democracy and economic growth. British Journal of Political Science 24(2), 225-248.

Henisz, W. J. (2000). The institutional environment for economic growth. Economics and Politics 12(1), 1-31.

Henisz, W. J. (2002). The institutional environment for infrastructure investment. Industrial and Corporate Change 11(2), 355-389.

Henisz, W. J. (2010). POLCON, Political Constraint Index, 2010 version, http://www-management.wharton.upenn.edu/henisz.

Heston, A., Summers, R., \& Aten, B. (2011). Penn World Table Version 7.1., November 2011, Center for International Comparisons of Production, Income and Prices, University of Pennsylvania.

Hobbes, T. ([1651] 1991). Leviathan, R. Tuck (Ed.). Cambridge: Cambridge University Press.

Justesen, M. K. (2008). The effect of economic freedom on growth revisited: New evidence on causality from a panel of countries 1970-1999. European Journal of Political Economy 24(3), 642-660.

Justesen, M. K. (2014). Better safe than sorry: How property rights and veto players jointly affect economic growth. Comparative Politics 46(2), forthcoming.

Justesen, M. K. \& Kurrild-Klitgaard, P. (2007). The constitution of economic growth: Testing the prosperity effects of a Madisonian model on a panel of countries 1980-2000, MRPA working paper 36063, Munich University Library, http://mpra.ub.uni-muenchen.de/36063/. 
Kapstein, E. B. \& Converse, N. (2008). The fate of young democracies. Cambridge: Cambridge University Press.

Kasper, W. \& Streit, M. E. (1998). Institutional economics: Social order and public policy. Cheltenham: Edward Elgar \& Locke Institute.

Keefer, P. (2007). Clientelism, credibility, and the policy choices of young democracies. American Journal of Political Science 51(4), 804-821.

Keefer, P. \& Knack, S. (1997). Why don't poor countries catch up? A crossnational test of institutional explanation. Economic Inquiry 35(3), 590-602.

Knack, S. \& Keefer, P. (1995). Institutions and economic performance: Crosscountry tests using alternative institutional measures. Economics and Politics 7(3), 207-227.

Krehbiel, K. (1996). Institutional and partisan sources of gridlock: A theory of divided and unified government. Journal of Theoretical Politics 8(1), 7-40.

Kurrild-Klitgaard, P. (2003). Frihedens forfatning: Velstand, regulering og skatter i konstitutionelt perspektiv. Økonomi \& Politik 76(2), 8-22.

Kurrild-Klitgaard, P. \& Berggren, N. (2004). Economic consequences of constitutions: A theory and survey. Journal des Economistes et des Etudes Humaines 14(1), 3-41.

Kydland, F. \& Prescott, E. C. (1977). Rules rather than discretion: The inconsistency of optimal plans. Journal of Political Economy 85(3), 473-492.

Leblang, D. A. (1996). Property rights, democracy and economy growth. Political Research Quarterly 49(1), 5-26.

Li, Q. \& Resnick, A. (2003). Reversal of fortunes: Democratic institutions and foreign direct investment inflows to developing countries. International Organization 57(1), 175-211.

Linz, J. J. (1994). Presidential or parliamentary democracy: Does it make a difference? In J. J. Linz \& A. Valenzula (Eds.), The failure of presidential democracy (pp. 3-70). Baltimore: Johns Hopkins University Press.

Linz, J. J. \& Stepan, A. C. (1996). Problems of democratic transition and consolidation: Southern Europe, South America, and Post-Communist Europe. Baltimore: Johns Hopkins University Press.

Madison, J. ([1792] 1906). Property. In G. Hunt (Ed.), The writings of James Madison (pp. 101-103), Vol. 1. New York: G.P. Putnam's Sons.

Marshall, J. B. \& Stone, R. W. (2012). Expropriation risk and strategic entry decisions in foreign direct investment, IPES working paper.

Martínez, O. G. \& King, L. (2010). Property rights reform and development: A critique of the cross-national regression literature Political Economy Research Institute, University of Massachusetts, Amherst, Amherst, http://scholarworks.umass.edu/peri workingpapers/190/. 
Melton, J. (2013). Credibly committing to property rights: The roles of reputation, institutions, and the constitution, working paper, https://netfiles.uiuc.edu/melton/Files/melton propertyrights.pdf.

Miller, G. J. \& Hammond, T. H. (1989). Stability and efficiency in a separation of powers constitutional system. In B. Grofman \& D. Wittman (Eds.), The Federalist Papers and the new institutionalism (pp. 85-99). New York: Agathon. Mises, L. v. ([1949] 1966). Human action: A treatise on economics (3. rev. ed.). Chicago: Henry Regnery.

Mises, L. v. ([1927] 2005). Liberalism: The classical tradition. Indianapolis: Liberty Fund.

Nickell, S. (1981). Biases in dynamic models with fixed effects. Econometrica 49(6), 1417-1426.

North, D. C. (1990). Institutions, institutional change and economic performance. Cambridge: Cambridge University Press.

North, D. C. (1992). Transaction costs, institutions, and economic performance. San Francisco: International Center for Economic Growth.

North, D. C. \& Thomas, R. P. (1973). The rise of the western world: A new economic history. Cambridge: Cambridge University Press.

North, D. C. \& Weingast, B. R. (1989). Constitutions and commitment: The evolution of institutions governing public choice in seventeenth-century England. Journal of Economic History 49(4), 803-832.

Nyström, K. (2008). The institutions of economic freedom and entrepreneurship: Evidence from panel data. Public Choice 136, 269-282.

O'Driscoll, G. P. \& Hoskins, L. (2003). Property rights: The key to economic development, Policy Analysis, 482. Washington: Cato Institute.

Olson, M. (2000). Power and prosperity: Outgrowing communist and capitalist dictatorships. New York: Basic Books.

Paldam, M. (2013). The political economy of Dutch disease: A survey. In F. Cabrillo \& M. A. Puchades-Navarro (Eds.), Constitutional economics and public institutions (pp. 179-196). Cheltenham: Edward Elgar.

Persson, T. \& Tabellini, G. (2009). Democratic capital: The nexus of political and economic change. American Economic Journal: Macroeconomics 1(2), 88-126.

Pipes, R. (1999). Property and freedom. New York: Vintage Books.

Przeworski, A., Alvarez, M. E., Cheibub, J. A., \& Limongi, F. (2000). Democracy and development: Political institutions and well-being in the world, 1950-1990. Cambridge: Cambridge University Press.

Robinson, J. A. \& Parsons, N. Q. (2006). State formation and governance in Botswana. Journal of African Economies 15(AERC Supplement), 100-140.

Rodrik, D., Subramanian, A., \& Trebbi, F. (2004). Institutions rule: The primacy of institutions over grography and integration in economic development. Journal of Economic Growth 9(2), 131-165. 
Ross, M. L. (2012). The oil curse: How petroleum wealth shapes the development of nations. Princeton: Princeton University Press.

Rothbard, M. N. (1956). Toward a reconstruction of utility and welfare economics. In M. Sennholz (Ed.), On freedom and free enterprise (pp. 224-262). Princeton: D. Van Nostrand.

Sachs, J. D. \& Warner, A. M. (2001). The curse of natural resources. European Economic Review 45, 827-838.

Scully, G. W. (2001). Institutions, policy, and economic growth. In W. F. Shughart \& L. Razzolini (Eds.), The Elgar companion to public choice (pp. 611627). Cheltenham: Edward Elgar.

Smith, A. ([1776] 1981). An inquiry into the nature and causes of the wealth of nations, R. H. Campbell \& A. S. Skinner (Eds.), Glasgow Edition of the Works and Correspondence of Adam Smith, Vol. I-II. Indianapolis: Liberty Press.

Torstensson, J. (1994). Property rights and economic growth: An empirical study. Kyklos 47, 231-247.

Tsebelis, G. (1995). Decision-making in political systems: Veto players in presidentialism, parliamentarism, multicameralism and multipartyism. British Journal of Political Science 25(3), 289-325.

Tsebelis, G. (2002). Veto players: How political institutions work. Princeton: Princeton University Press.

Tullock, G. (1974). The social dilemma: The economics of war and revolution. Blacksburg: Center for Study of Public Choice.

Vanssay, X. d. \& Spindler, Z. A. (1994). Freedom and growth: Do constitutions matter? Public Choice 78(3-4), 359-372.

Wagner, R. E. (1993). Parchment, guns and constitutional order. Cheltenham: Edward Elgar.

Weaver, R. K. \& Rockman, B. A. (1993a). Assessing the effects of institutions. In R. K. Weaver \& B. A. Rockman (Eds.), Do institutions matter? Government capabilities in the United States and abroad (pp. 1-41). Washington: Brookings Institution.

Weaver, R. K. \& Rockman, B. A. (Eds.) (1993b). Do institutions matter? Government capabilities in the United States and abroad. Washington: Brookings Institution.

Weingast, B. R. (1993). Constitutions as governance structures: The political foundations of secure markets. Journal of Institutional and Theoretical Economics 149, 286-311.

Weingast, B. R. (1995). The economic role of political institutions: Marketpreserving federalism and economic development. Journal of Law, Economics and Organization 11(1), 1-31. 
Weymouth, S. (2011). Political institutions and property rights: Veto players and foreign exchange commitments in 127 countries. Comparative Political Studies 44(2), 211-240. 
Table 1. Institutions and economic growth: Interaction effects of property rights and veto players.

\begin{tabular}{|c|c|c|c|c|c|c|c|c|c|c|c|c|}
\hline Model & 1 & 2 & 3 & 4 & 5 & 6 & 7 & 8 & 9 & 10 & 11 & 12 \\
\hline Method & FE & GMM & FE & GMM & $\mathrm{FE}$ & GMM & FE & GMM & FE & GMM & FE & GMM \\
\hline Sample & World & World & LDC & LDC & World & World & LDC & LDC & World & World & LDC & LDC \\
\hline Property rightst-1 & $\begin{array}{c}0.29 \\
(0.39)\end{array}$ & $\begin{array}{l}-1.67^{*} \\
(1.79)\end{array}$ & $\begin{array}{c}0.50 \\
(0.59)\end{array}$ & $\begin{array}{l}-1.65 \\
(1.57)\end{array}$ & $\begin{array}{l}-0.03 \\
(0.04)\end{array}$ & $\begin{array}{l}-2.02^{*} \\
(1.92)\end{array}$ & $\begin{array}{c}0.23 \\
(0.24)\end{array}$ & $\begin{array}{l}-2.29^{*} \\
(1.95)\end{array}$ & $\begin{array}{c}1.02 \\
(0.87)\end{array}$ & $\begin{array}{l}-0.30 \\
(0.18)\end{array}$ & $\begin{array}{c}1.34 \\
(1.13)\end{array}$ & $\begin{array}{c}0.40 \\
(0.26)\end{array}$ \\
\hline POLCONt-1 & $\begin{array}{r}-13.40 \\
(1.11)\end{array}$ & $\begin{array}{c}-36.48^{* *} \\
(2.45)\end{array}$ & $\begin{array}{l}-24.27 \\
(1.65)\end{array}$ & $\begin{array}{c}-46.14^{* * *} \\
(2.78)\end{array}$ & & & & & & & & \\
\hline Leg. chamberst-1 & & & & & $\begin{array}{l}-4.35 \\
(1.35)\end{array}$ & $\begin{array}{c}-14.67^{* * *} \\
(2.97)\end{array}$ & $\begin{array}{l}-6.26 \\
(1.55)\end{array}$ & $\begin{array}{c}-14.87^{* * *} \\
(2.68)\end{array}$ & & & & \\
\hline Leg. fract.t-1 & & & & & & & & & $\begin{array}{l}12.87 \\
(1.17)\end{array}$ & $\begin{array}{l}18.91 \\
(1.15)\end{array}$ & $\begin{array}{l}11.09 \\
(0.97)\end{array}$ & $\begin{array}{l}12.36 \\
(0.84)\end{array}$ \\
\hline Prop $^{*}$ POLCONt & $\begin{array}{c}2.99 \\
(1.48)\end{array}$ & $\begin{array}{c}8.63^{* * *} \\
(3.39)\end{array}$ & $\begin{array}{l}5.27^{*} \\
(1.93)\end{array}$ & $\begin{array}{c}10.64^{* * *} \\
(3.11)\end{array}$ & & & & & & & & \\
\hline Prop*Chambers.t-1 & & & & & $\begin{array}{l}1.06^{*} \\
(1.78)\end{array}$ & $\begin{array}{c}2.57^{* * *} \\
(3.03)\end{array}$ & $\begin{array}{l}1.43^{*} \\
(1.83)\end{array}$ & $\begin{array}{c}3.01^{* * *} \\
(2.82)\end{array}$ & & & & \\
\hline Prop ${ }^{*}$ Leg. fract.t-1 & & & & & & & & & $\begin{array}{c}0.05 \\
(0.02)\end{array}$ & $\begin{array}{c}1.86 \\
(0.69)\end{array}$ & $\begin{array}{c}0.69 \\
(0.31)\end{array}$ & $\begin{array}{c}1.81 \\
(0.66)\end{array}$ \\
\hline Democracyt-1 & $\begin{array}{c}2.32 \\
(0.83)\end{array}$ & $\begin{array}{c}0.79 \\
(0.18)\end{array}$ & $\begin{array}{c}2.46 \\
(0.78)\end{array}$ & $\begin{array}{c}0.11 \\
(0.03)\end{array}$ & $\begin{array}{c}2.04 \\
(0.72)\end{array}$ & $\begin{array}{c}4.97 \\
(0.99)\end{array}$ & $\begin{array}{c}2.55 \\
(0.85)\end{array}$ & $\begin{array}{c}2.47 \\
(0.53)\end{array}$ & $\begin{array}{c}0.21 \\
(0.09)\end{array}$ & $\begin{array}{l}-9.29^{* *} \\
(2.03)\end{array}$ & $\begin{array}{l}-0.32 \\
(0.13)\end{array}$ & $\begin{array}{l}-6.63 \\
(1.47)\end{array}$ \\
\hline Stability t-1 & $\begin{array}{l}-0.05 \\
(0.87)\end{array}$ & $\begin{array}{l}-0.06 \\
(0.54)\end{array}$ & $\begin{array}{l}-0.04 \\
(0.55)\end{array}$ & $\begin{array}{l}-0.15 \\
(1.36)\end{array}$ & $\begin{array}{l}-0.04 \\
(0.72)\end{array}$ & $\begin{array}{l}-0.03 \\
(0.23)\end{array}$ & $\begin{array}{l}-0.03 \\
(0.49)\end{array}$ & $\begin{array}{l}-0.15 \\
(1.29)\end{array}$ & $\begin{array}{l}-0.03 \\
(0.46)\end{array}$ & $\begin{array}{l}-0.02 \\
(0.16)\end{array}$ & $\begin{array}{l}-0.01 \\
(0.08)\end{array}$ & $\begin{array}{l}-0.08 \\
(0.63)\end{array}$ \\
\hline Battle deathst-1 & $\begin{array}{c}-10.03^{* * *} \\
(2.93)\end{array}$ & $\begin{array}{c}-13.08^{* * *} \\
(3.71)\end{array}$ & $\begin{array}{c}-8.32^{* *} \\
(2.13)\end{array}$ & $\begin{array}{c}-12.34^{* * *} \\
(4.00)\end{array}$ & $\begin{array}{c}-10.09^{* * *} \\
(2.95)\end{array}$ & $\begin{array}{c}-12.72^{* * *} \\
(3.98)\end{array}$ & $\begin{array}{c}-8.46^{* *} \\
(2.18)\end{array}$ & $\begin{array}{c}-12.49^{* * *} \\
(4.27)\end{array}$ & $\begin{array}{c}-9.94^{* *} \\
(2.12)\end{array}$ & $\begin{array}{c}-13.86^{* * *} \\
(3.63)\end{array}$ & $\begin{array}{l}-7.97 \\
(1.45)\end{array}$ & $\begin{array}{c}-11.07^{* * *} \\
(2.90)\end{array}$ \\
\hline $\log (G D P / c a p) t-1$ & $\begin{array}{c}-26.16^{* * *} \\
(7.58)\end{array}$ & $\begin{array}{c}-43.16^{* * *} \\
(6.00)\end{array}$ & $\begin{array}{c}-23.54^{* * *} \\
(6.85)\end{array}$ & $\begin{array}{c}-35.40^{* * *} \\
(5.24)\end{array}$ & $\begin{array}{c}-26.13^{* * *} \\
(7.31)\end{array}$ & $\begin{array}{c}-41.90^{* * *} \\
(6.22)\end{array}$ & $\begin{array}{c}-23.36^{* * *} \\
(6.50)\end{array}$ & $\begin{array}{c}-33.38^{* * *} \\
(5.13)\end{array}$ & $\begin{array}{c}-24.24^{* * *} \\
(6.16)\end{array}$ & $\begin{array}{c}-39.39^{* * *} \\
(5.21)\end{array}$ & $\begin{array}{c}-20.98^{* * *} \\
(5.39)\end{array}$ & $\begin{array}{c}-33.37^{* * *} \\
(4.57)\end{array}$ \\
\hline Pop. growtht-1 & $\begin{array}{l}14.46 \\
(0.80)\end{array}$ & $\begin{array}{c}45.01^{* * *} \\
(2.67)\end{array}$ & $\begin{array}{l}16.80 \\
(1.05)\end{array}$ & $\begin{array}{c}43.89^{* * *} \\
(2.67)\end{array}$ & $\begin{array}{l}14.52 \\
(0.80)\end{array}$ & $\begin{array}{c}37.60^{* *} \\
(2.35)\end{array}$ & $\begin{array}{l}16.74 \\
(1.05)\end{array}$ & $\begin{array}{c}36.57^{* *} \\
(2.45)\end{array}$ & $\begin{array}{l}12.09 \\
(0.61)\end{array}$ & $\begin{array}{l}34.15 \\
(1.60)\end{array}$ & $\begin{array}{c}9.13 \\
(0.54)\end{array}$ & $\begin{array}{c}32.00^{*} \\
(1.75)\end{array}$ \\
\hline Schooling $\mathrm{t}_{\mathrm{t}-1}$ & $\begin{array}{l}-1.21 \\
(1.29)\end{array}$ & $\begin{array}{l}-2.04 \\
(1.12)\end{array}$ & $\begin{array}{l}-2.12 \\
(1.52)\end{array}$ & $\begin{array}{l}-2.27 \\
(0.99)\end{array}$ & $\begin{array}{l}-1.25 \\
(1.34)\end{array}$ & $\begin{array}{l}-2.65 \\
(1.58)\end{array}$ & $\begin{array}{l}-2.07 \\
(1.51)\end{array}$ & $\begin{array}{l}-1.85 \\
(0.83)\end{array}$ & $\begin{array}{l}-1.70^{*} \\
(1.68)\end{array}$ & $\begin{array}{l}-1.89 \\
(0.87)\end{array}$ & $\begin{array}{l}-2.97^{*} \\
(1.95)\end{array}$ & $\begin{array}{l}-2.33 \\
(0.84)\end{array}$ \\
\hline Trade volumest-1 & $\begin{array}{c}0.10^{* * *} \\
(2.64)\end{array}$ & $\begin{array}{l}0.17^{* *} \\
(2.27)\end{array}$ & $\begin{array}{l}0.08^{* *} \\
(2.11)\end{array}$ & $\begin{array}{l}0.23^{* *} \\
(2.57)\end{array}$ & $\begin{array}{c}0.10^{* * *} \\
(2.68)\end{array}$ & $\begin{array}{l}0.18^{* *} \\
(2.03)\end{array}$ & $\begin{array}{l}0.09^{* *} \\
(2.18)\end{array}$ & $\begin{array}{l}0.25^{* *} \\
(2.38)\end{array}$ & $\begin{array}{c}0.10^{* * *} \\
(2.71)\end{array}$ & $\begin{array}{l}0.23^{* *} \\
(2.56)\end{array}$ & $\begin{array}{l}0.08^{* *} \\
(2.21)\end{array}$ & $\begin{array}{l}0.25^{* *} \\
(2.35)\end{array}$ \\
\hline Oil productiont-1 & $\begin{array}{l}-25.61 \\
(1.15)\end{array}$ & $\begin{array}{l}-1.23 \\
(0.04)\end{array}$ & $\begin{array}{c}-56.46^{* *} \\
(2.24)\end{array}$ & $\begin{array}{l}-19.45 \\
(0.88)\end{array}$ & $\begin{array}{l}-24.73 \\
(1.11)\end{array}$ & $\begin{array}{l}-0.76 \\
(0.03)\end{array}$ & $\begin{array}{c}-55.82^{* *} \\
(2.27)\end{array}$ & $\begin{array}{l}-18.89 \\
(0.99)\end{array}$ & $\begin{array}{l}-32.70 \\
(1.10)\end{array}$ & $\begin{array}{l}-46.34 \\
(1.34)\end{array}$ & $\begin{array}{c}-85.44^{* * *} \\
(3.59)\end{array}$ & $\begin{array}{c}-68.27^{* * *} \\
(3.31)\end{array}$ \\
\hline Obs./countries & $676 / 108$ & $568 / 108$ & $509 / 86$ & $423 / 86$ & $676 / 108$ & $568 / 108$ & $509 / 86$ & $423 / 86$ & $624 / 106$ & $512 / 106$ & $462 / 84$ & $373 / 84$ \\
\hline$R^{2}$ & 0.286 & - & 0.328 & - & 0.287 & - & 0.327 & - & 0.288 & - & 0.340 & - \\
\hline
\end{tabular}

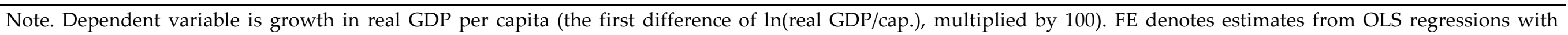


country fixed effects. GMM denotes estimates from Arellano-Bond GMM regressions. All models include period fixed effects. Standard errors are robust and clustered by country (absolute value of $\mathrm{z}$-statistics in parentheses). ${ }^{* * *} \mathrm{p}<0.01,{ }^{* *} \mathrm{p}<0.05,{ }^{*} \mathrm{p}<0.1$. 
36

Table 2. Institutions and economic growth: Interactions in countries with low and high stocks of democratic capital

\begin{tabular}{|c|c|c|c|c|c|c|c|c|c|c|c|c|}
\hline Model & 1 & 2 & 3 & 4 & 5 & 6 & 7 & 8 & 9 & 10 & 11 & 12 \\
\hline Method & FE & FE & GMM & GMM & FE & FE & GMM & GMM & FE & FE & GMM & GMM \\
\hline $\begin{array}{l}\text { Democratic } \\
\text { capital stock }\end{array}$ & Low & High & Low & High & Low & High & Low & High & Low & High & Low & High \\
\hline Property rightst- 1 & $\begin{array}{c}0.06 \\
(0.03)\end{array}$ & $\begin{array}{l}-0.62 \\
(0.47)\end{array}$ & $\begin{array}{l}-0.51 \\
(0.30)\end{array}$ & $\begin{array}{l}-2.21 \\
(1.49)\end{array}$ & $\begin{array}{l}-0.44 \\
(0.23)\end{array}$ & $\begin{array}{l}-0.24 \\
(0.16)\end{array}$ & $\begin{array}{l}-1.95 \\
(1.02)\end{array}$ & $\begin{array}{l}-1.05 \\
(0.71)\end{array}$ & $\begin{array}{c}2.71 \\
(0.50)\end{array}$ & $\begin{array}{l}-2.75 \\
(1.28)\end{array}$ & $\begin{array}{c}1.96 \\
(0.57)\end{array}$ & $\begin{array}{l}-0.22 \\
(0.10)\end{array}$ \\
\hline POLCON ${ }_{\mathrm{t}-1}$ & $\begin{array}{l}-11.88 \\
(0.56)\end{array}$ & $\begin{array}{c}-57.90^{* *} \\
(2.59)\end{array}$ & $\begin{array}{l}-22.24 \\
(1.04)\end{array}$ & $\begin{array}{c}-68.82^{* * *} \\
(3.34)\end{array}$ & - & - & - & - & - & - & - & - \\
\hline Leg. chamberst-1 & - & - & - & - & $\begin{array}{l}-11.19 \\
(1.13)\end{array}$ & $\begin{array}{c}-14.83^{* *} \\
(2.60)\end{array}$ & $\begin{array}{l}-15.72^{*} \\
(1.70)\end{array}$ & $\begin{array}{c}-16.78^{* * *} \\
(3.09)\end{array}$ & - & - & - & - \\
\hline Leg. fract.t-1 & - & - & - & - & - & - & - & - & $\begin{array}{l}28.11 \\
(0.58)\end{array}$ & $\begin{array}{l}-28.79 \\
(1.31)\end{array}$ & $\begin{array}{l}60.10^{*} \\
(1.69)\end{array}$ & $\begin{array}{l}-2.90 \\
(0.15)\end{array}$ \\
\hline Prop $^{*}$ POLCONt-1 & $\begin{array}{c}4.60 \\
(0.90)\end{array}$ & $\begin{array}{c}10.67^{* *} \\
(2.45)\end{array}$ & $\begin{array}{c}6.17 \\
(1.39)\end{array}$ & $\begin{array}{c}12.57^{* * *} \\
(2.87)\end{array}$ & - & - & - & - & - & - & - & - \\
\hline $\begin{array}{l}\text { Prop }{ }^{*} \text { Chamberst- } \\
1\end{array}$ & - & - & - & - & $\begin{array}{c}2.77 \\
(1.12)\end{array}$ & $\begin{array}{l}2.78^{* *} \\
(2.64)\end{array}$ & $\begin{array}{l}4.01^{* *} \\
(2.11)\end{array}$ & $\begin{array}{l}2.96^{* * *} \\
(2.74)\end{array}$ & - & - & - & - \\
\hline Prop ${ }^{*}$ Leg. fractt- 1 & - & - & - & - & - & - & - & - & $\begin{array}{l}-2.16 \\
(0.27)\end{array}$ & $\begin{array}{l}9.57^{*} \\
(1.92)\end{array}$ & $\begin{array}{l}-5.36 \\
(0.98)\end{array}$ & $\begin{array}{c}3.56 \\
(0.87)\end{array}$ \\
\hline Stability t-1 & $\begin{array}{l}-0.90^{*} \\
(1.90)\end{array}$ & $\begin{array}{l}-0.15 \\
(0.61)\end{array}$ & $\begin{array}{l}-0.19 \\
(0.91)\end{array}$ & $\begin{array}{l}-0.10 \\
(0.30)\end{array}$ & $\begin{array}{l}-0.89 * \\
(1.98)\end{array}$ & $\begin{array}{l}-0.14 \\
(0.55)\end{array}$ & $\begin{array}{l}-0.14 \\
(0.73)\end{array}$ & $\begin{array}{l}-0.01 \\
(0.04)\end{array}$ & $\begin{array}{l}-0.83 \\
(1.39)\end{array}$ & $\begin{array}{c}0.01 \\
(0.05)\end{array}$ & $\begin{array}{l}-0.11 \\
(0.55)\end{array}$ & $\begin{array}{c}0.28 \\
(0.92)\end{array}$ \\
\hline Battle deathst-1 & $\begin{array}{l}-7.12 \\
(1.39)\end{array}$ & $\begin{array}{l}22.86 \\
(1.10)\end{array}$ & $\begin{array}{c}-13.75^{* * *} \\
(3.98)\end{array}$ & $\begin{array}{c}29.67^{* *} \\
(2.01)\end{array}$ & $\begin{array}{l}-7.27 \\
(1.64)\end{array}$ & $\begin{array}{l}18.91 \\
(1.10)\end{array}$ & $\begin{array}{c}-13.69^{* * *} \\
(3.42)\end{array}$ & $\begin{array}{l}19.07^{*} \\
(1.76)\end{array}$ & $\begin{array}{l}-6.47 \\
(0.97)\end{array}$ & $\begin{array}{l}11.68 \\
(0.70)\end{array}$ & $\begin{array}{c}-18.66^{* * *} \\
(5.67)\end{array}$ & $\begin{array}{c}23.98^{* *} \\
(2.16)\end{array}$ \\
\hline $\ln (\mathrm{GDP} / \mathrm{cap}) \mathrm{t}-1$ & $\begin{array}{c}-40.16^{* * *} \\
(6.06)\end{array}$ & $\begin{array}{c}-34.55^{* * *} \\
(5.25)\end{array}$ & $\begin{array}{c}-39.30^{* * *} \\
(4.45)\end{array}$ & $\begin{array}{c}-53.19^{* * *} \\
(8.69)\end{array}$ & $\begin{array}{c}-40.64^{* * *} \\
(6.35)\end{array}$ & $\begin{array}{c}-32.83^{* * *} \\
(4.57)\end{array}$ & $\begin{array}{c}-39.30^{* * *} \\
(4.70)\end{array}$ & $\begin{array}{c}-54.35^{* * *} \\
(7.09)\end{array}$ & $\begin{array}{c}-35.60^{* * *} \\
(3.45)\end{array}$ & $\begin{array}{c}-27.95^{* * *} \\
(4.97)\end{array}$ & $\begin{array}{c}-25.08^{* * *} \\
(2.84)\end{array}$ & $\begin{array}{c}-59.41^{* * *} \\
(6.81)\end{array}$ \\
\hline Pop. growtht-1 & $\begin{array}{c}118.53^{* *} \\
(2.54)\end{array}$ & $\begin{array}{r}-36.09 \\
(0.37)\end{array}$ & $\begin{array}{l}57.82 \\
(1.30)\end{array}$ & $\begin{array}{l}15.30 \\
(0.27)\end{array}$ & $\begin{array}{c}112.13^{* *} \\
(2.36)\end{array}$ & $\begin{array}{r}-43.48 \\
(0.45)\end{array}$ & $\begin{array}{l}51.50 \\
(1.31)\end{array}$ & $\begin{array}{l}24.12 \\
(0.39)\end{array}$ & $\begin{array}{c}118.37 \\
(1.40)\end{array}$ & $\begin{array}{c}-71.48 \\
(0.74)\end{array}$ & $\begin{array}{l}-0.53 \\
(0.01)\end{array}$ & $\begin{array}{l}-5.15 \\
(0.08)\end{array}$ \\
\hline Schooling ${ }_{t-1}$ & $\begin{array}{c}8.80 \\
(1.24)\end{array}$ & $\begin{array}{c}-4.49 \\
(-1.56)\end{array}$ & $\begin{array}{c}10.71^{* *} \\
(2.24)\end{array}$ & $\begin{array}{c}-3.55 \\
(-1.17)\end{array}$ & $\begin{array}{c}9.60 \\
(1.45)\end{array}$ & $\begin{array}{l}-5.65^{*} \\
(-1.95)\end{array}$ & $\begin{array}{c}12.52^{* *} \\
(2.55)\end{array}$ & $\begin{array}{l}-5.97^{*} \\
(-1.74)\end{array}$ & $\begin{array}{c}5.72 \\
(0.75)\end{array}$ & $\begin{array}{l}-5.37^{* *} \\
(-2.33)\end{array}$ & $\begin{array}{c}8.75^{* * *} \\
(2.63)\end{array}$ & $\begin{array}{c}-3.30 \\
(-0.97)\end{array}$ \\
\hline Trade volumest- 1 & $\begin{array}{l}-0.00 \\
(0.03)\end{array}$ & $\begin{array}{c}0.10 \\
(1.20)\end{array}$ & $\begin{array}{c}-0.03 \\
(0.28)\end{array}$ & $\begin{array}{l}0.17^{*} \\
(1.65)\end{array}$ & $\begin{array}{c}0.01 \\
(0.04)\end{array}$ & $\begin{array}{c}0.11 \\
(1.27)\end{array}$ & $\begin{array}{c}0.02 \\
(0.25)\end{array}$ & $\begin{array}{l}0.23^{* *} \\
(2.25)\end{array}$ & $\begin{array}{c}0.10 \\
(0.71)\end{array}$ & $\begin{array}{c}0.10 \\
(1.21)\end{array}$ & $\begin{array}{c}0.12 \\
(1.06)\end{array}$ & $\begin{array}{c}0.12 \\
(1.12)\end{array}$ \\
\hline Oil productiont-1 & $\begin{array}{c}-1746.9^{* * *} \\
(8.89)\end{array}$ & $\begin{array}{l}46.05 \\
(0.75)\end{array}$ & $\begin{array}{c}-1343.8^{* * *} \\
(7.04)\end{array}$ & $\begin{array}{l}80.14 \\
(1.32)\end{array}$ & $\begin{array}{c}-1769.8^{* * *} \\
(8.62)\end{array}$ & $\begin{array}{l}47.09 \\
(0.82)\end{array}$ & $\begin{array}{c}-1387.9^{* * *} \\
(7.00)\end{array}$ & $\begin{array}{l}97.34^{*} \\
(1.88)\end{array}$ & $\begin{array}{c}-1170.4^{* * *} \\
(5.28)\end{array}$ & $\begin{array}{l}39.40 \\
(0.69)\end{array}$ & $\begin{array}{c}-1001.7^{* * *} \\
(4.81)\end{array}$ & $\begin{array}{c}108.2^{* *} \\
(1.98)\end{array}$ \\
\hline Obs./countries & $95 / 40$ & $195 / 49$ & $76 / 37$ & $176 / 49$ & $95 / 40$ & $195 / 49$ & $76 / 37$ & $176 / 49$ & $87 / 40$ & $184 / 49$ & $64 / 36$ & $162 / 49$ \\
\hline
\end{tabular}




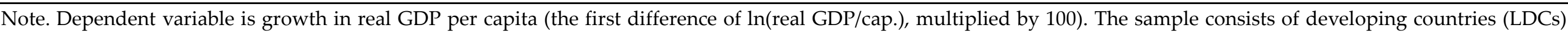

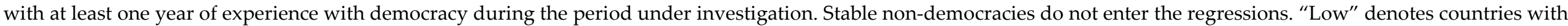

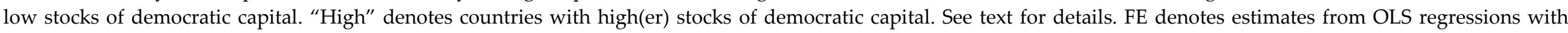

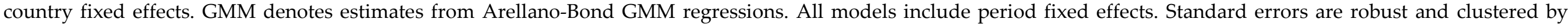
country (absolute value of $\mathrm{z}$-statistics in parentheses). ${ }^{* *} \mathrm{p}<0.01,{ }^{* *} \mathrm{p}<0.05,{ }^{*} \mathrm{p}<0.1$. 


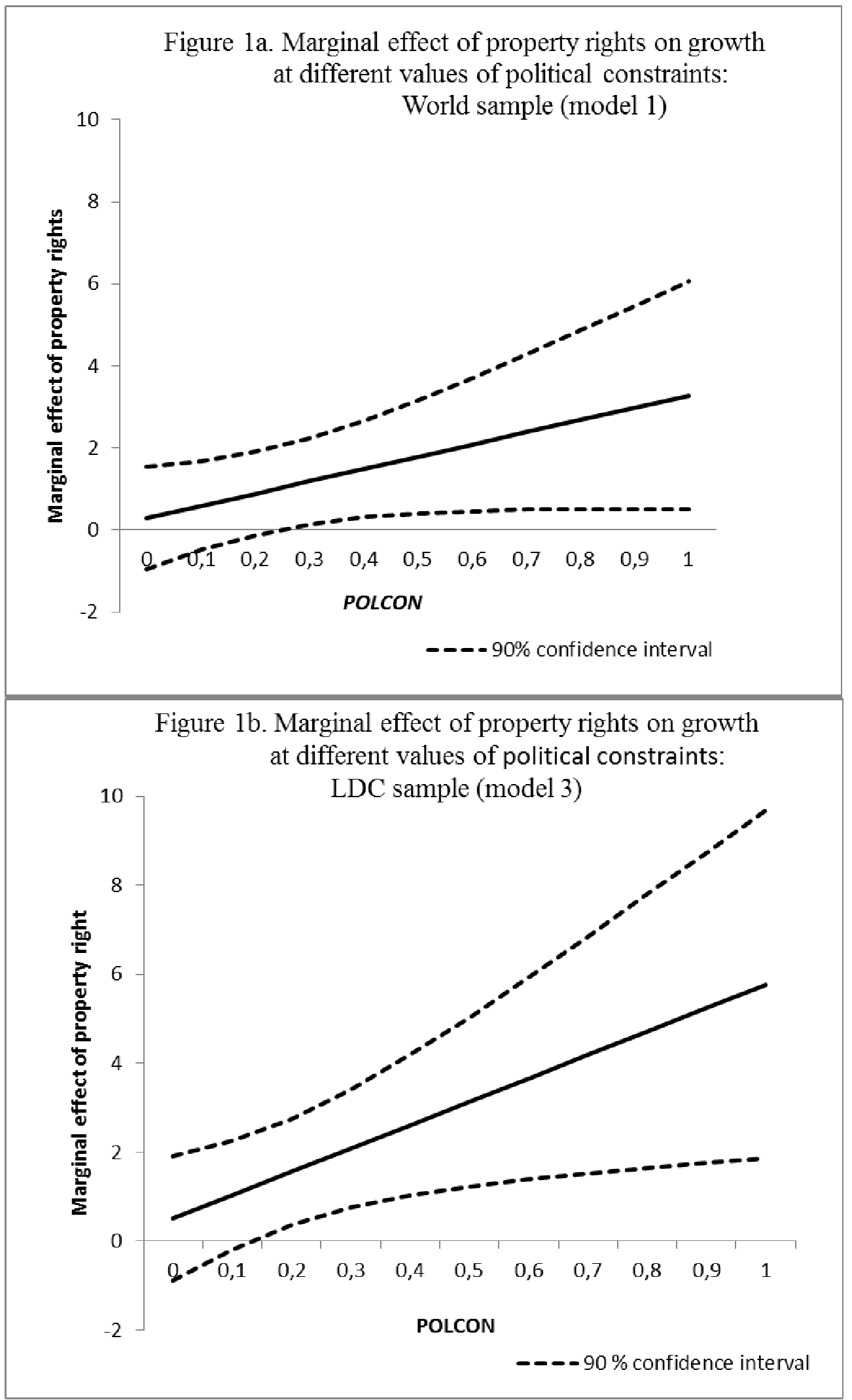




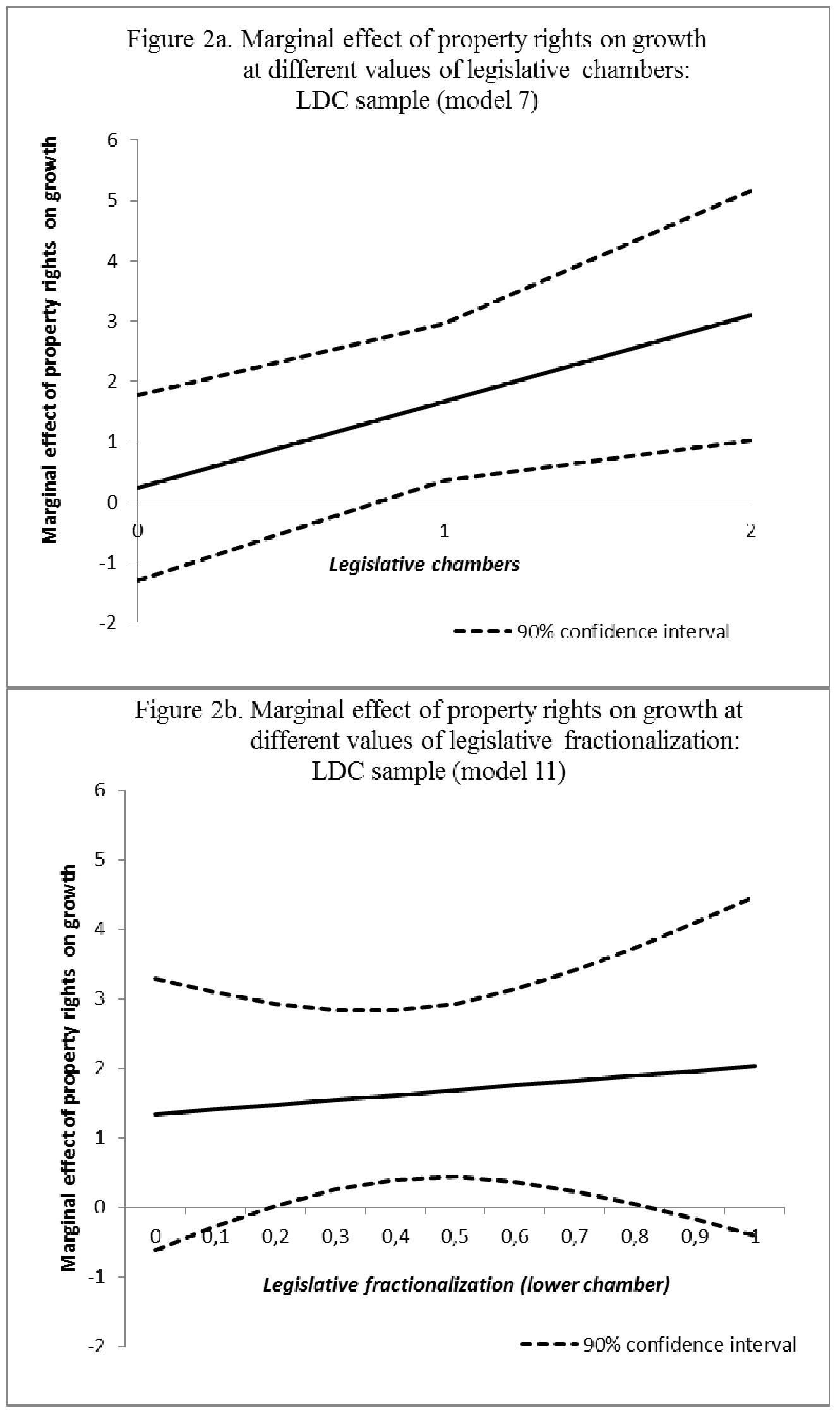




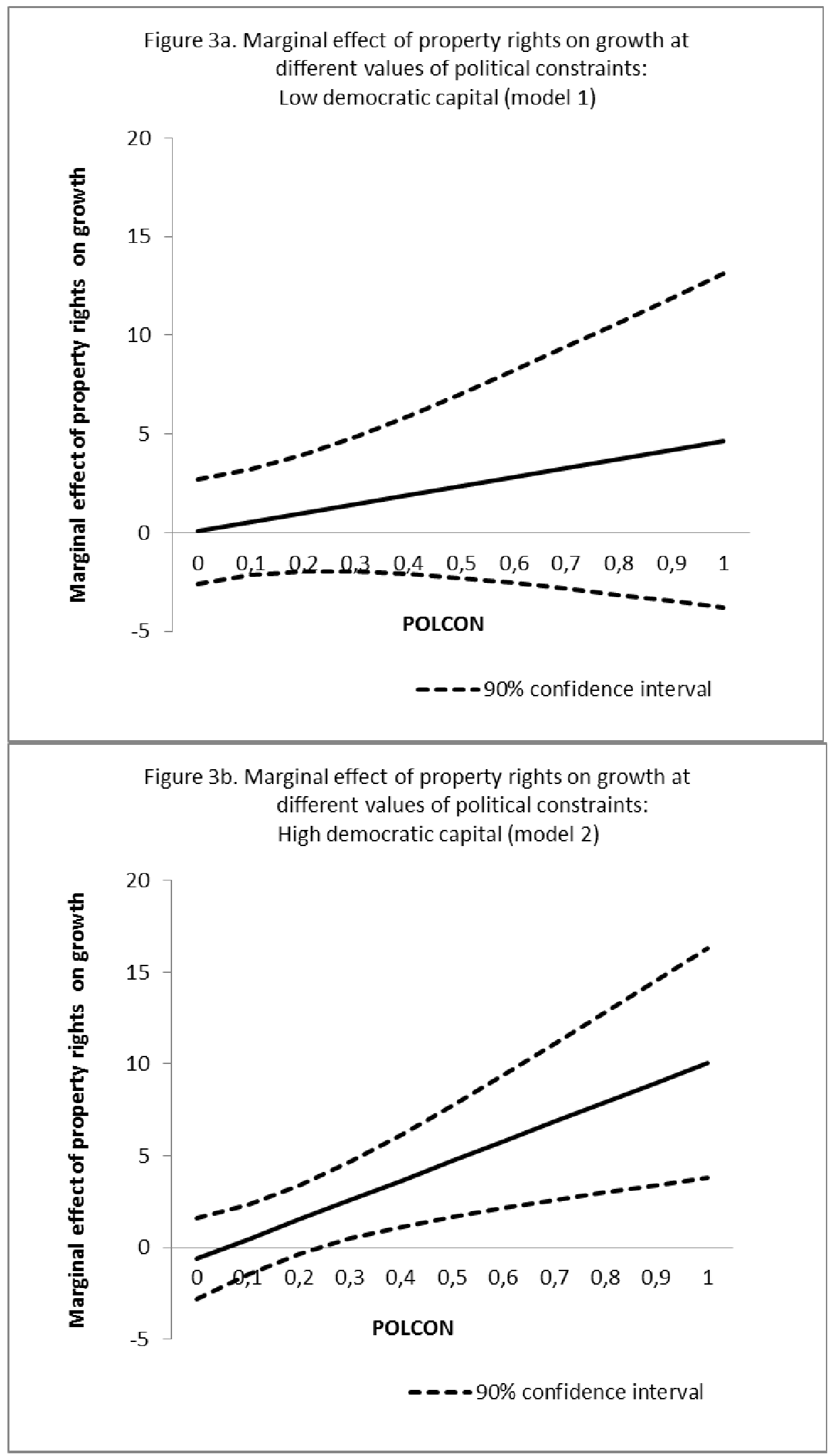




\begin{tabular}{|c|c|c|c|c|c|c|c|c|}
\hline Variable description & Source & Mean & $\begin{array}{l}\text { Std.dev. } \\
\text { (overall) }\end{array}$ & $\begin{array}{l}\text { Std.dev. } \\
\text { (within) }\end{array}$ & Min & $\operatorname{Max}$ & $\mathbf{N}$ & Obs. \\
\hline $\begin{array}{l}\text { Real economic growth over five-year intervals (1970- } \\
1975 \text { etc.). First difference of } \ln (\text { real GDP per capita), } \\
\text { multiplied by } 100 .\end{array}$ & $\begin{array}{l}\text { Penn World Tables, mark } 7.1 \\
\text { (Heston, Summers and Aten 2011). }\end{array}$ & 10.04 & 18.52 & 16.64 & -115.66 & 202 & 187 & 1,713 \\
\hline Property rights (see text for details). & $\begin{array}{l}\text { Area } 2 \text { from Fraser Institute } \\
\text { (Gwartney et al. 2011). Economic } \\
\text { Freedom of the World. } \\
\text { www.fraserinstitute.org }\end{array}$ & 5.71 & 2.17 & 0.98 & 1.19 & 9.89 & 123 & 780 \\
\hline Political constraints, POLCON (see text for details). & $\begin{array}{l}\text { POLCONIII (2000). Data from } \\
\text { updated } 2010 \text { edition (Henisz [2002] } \\
\text { 2010). }\end{array}$ & 0.19 & 0.21 & 0.12 & 0 & 0.72 & 190 & 1,598 \\
\hline Interaction: Property rights $\times$ POLCON & As above. & 1.75 & 1.65 & 0.76 & 0 & 6.62 & 123 & 780 \\
\hline Legislative chambers & $\begin{array}{l}\text { POLCONIII (2000). Data from } \\
\text { updated } 2010 \text { edition (Henisz [2002] } \\
\text { 2010). }\end{array}$ & 0.77 & 0.68 & 0.39 & 0 & 2 & 190 & 1,626 \\
\hline Interaction: Property rights $\times$ legislative chambers & As above. & 6.05 & 5.25 & 2.28 & 0 & 19.74 & 123 & 776 \\
\hline $\begin{array}{l}\text { Legislative fractionalization in first chamber (see text } \\
\text { for details). }\end{array}$ & $\begin{array}{l}\text { POLCONIII (2000). Data from } \\
\text { updated } 2010 \text { edition (Henisz [2002] } \\
\text { 2010). }\end{array}$ & 0.42 & 0.29 & 0.17 & 0 & 1 & 181 & 1,293 \\
\hline $\begin{array}{l}\text { Interaction: Property rights } \times \text { legislative } \\
\text { fractionalization }\end{array}$ & As above. & 3.12 & 2.16 & 0.97 & 0 & 8.27 & 118 & 696 \\
\hline $\begin{array}{l}\text { Democracy. Electoral contestation dummy. } \\
1=\text { Democracy; } 0=\text { non-democracy }\end{array}$ & $\begin{array}{l}\text { Cheibub, Gandhi and Vreeland } \\
2010 .\end{array}$ & 0.43 & 0.48 & 0.25 & 0 & 1 & 188 & 1,596 \\
\hline $\begin{array}{l}\text { Regime stability. Number of years regime has been } \\
\text { democracy or autocracy. }\end{array}$ & $\begin{array}{l}\text { Database of Political Institutions } \\
\text { (Beck et al. 2001; cf. Keefer 2007). }\end{array}$ & 20.88 & 27.79 & 12.61 & 0 & 196 & 161 & 1,513 \\
\hline $\begin{array}{l}\text { Battle deaths. Number of battle deaths in conflicts } \\
\text { causing more than } 25 \text { battle deaths annually. } \\
\text { Divided by population size. }\end{array}$ & $\begin{array}{l}\text { PRIO/Uppsala Conflict data. } \\
\text { http://www.prio.no/Data/Armed- } \\
\text { Conflict/UCDP-PRIO/ }\end{array}$ & 0.05 & 0.64 & 0.60 & 0 & 23.67 & 185 & 1,838 \\
\hline $\begin{array}{l}\text { Ln(GDP per capita). Natural log of real gross } \\
\text { domestic product per capita. }\end{array}$ & $\begin{array}{l}\text { Penn World Tables, mark } 7.1 \\
\text { (Heston, Summers and Aten 2011). }\end{array}$ & 8.25 & 1.27 & 0.40 & 5.08 & 11.38 & 187 & 1,713 \\
\hline $\begin{array}{l}\text { Population growth. First difference of }(\log ) \text { domestic } \\
\text { population size }\end{array}$ & $\begin{array}{l}\text { Penn World Tables, mark } 7.1 \\
\text { (Heston, Summers and Aten 2011). }\end{array}$ & 0.10 & 0.07 & 0.05 & -0.25 & 0.74 & 187 & 2,057 \\
\hline Average years of schooling. & $\begin{array}{l}\text { Barro-Lee educational attainment } \\
\text { data (Barro and Lee 2010), } 2012 \\
\text { update. }\end{array}$ & 5.27 & 3.05 & 1.69 & 0.01 & 12.91 & 145 & 1,740 \\
\hline Trade volumes: Exports + imports as percentage of & Penn World Tables, mark 7.1 & 74.05 & 49.17 & 22.35 & 2.01 & 430.56 & 187 & 1,717 \\
\hline
\end{tabular}

GDP.

(Heston, Summers and Aten 2011). 
Oil production per capita. Daily oil production (in $\quad$ BP Statistical Review of World

Further statistical details are available from the authors. 